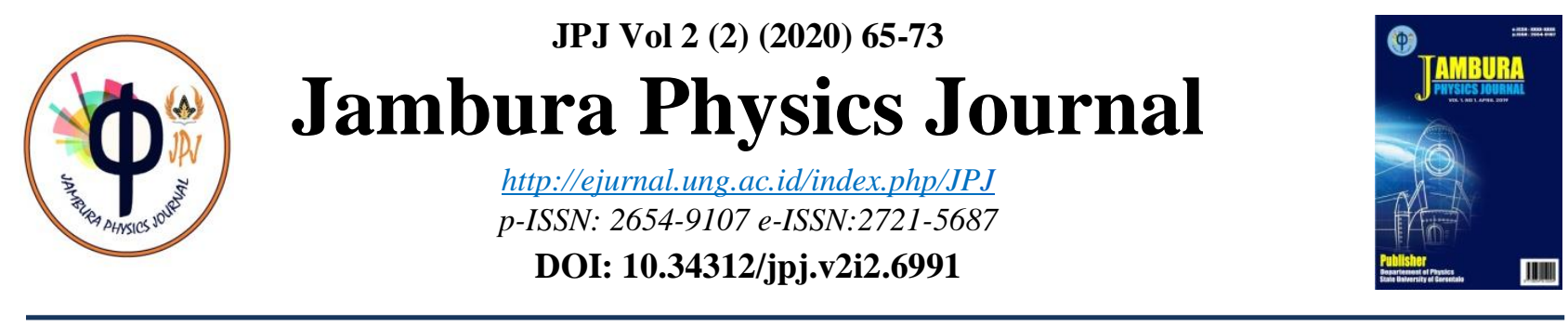

\title{
MENINGKATKAN KEMAMPUAN BERPIKIR KRITIS SISWA DENGAN MENGGUNAKAN MODEL PEMBELAJARAN INKUIRI TERBIMBING PADA MATERI SUHU DAN KALOR DI KELAS VII ${ }^{6}$ SMP NEGERI 1 TELAGA
}

\author{
Jihan Olii ${ }^{1}$, Ritin Uloli ${ }^{2}$ dan Abdul Haris Odja ${ }^{2 *}$ \\ ${ }^{1}$ Program Studi S1 Pendidikan IPA Universitas Negeri Gorontalo \\ ${ }^{2}$ Program Studi S1 Pendidikan Fisika Universitas Negeri Gorontalo \\ Jl. Jenderal Sudirman No 06 Kota Gorontalo
}

Accepted: Juli 9 2020. Approved: Agustus 30 2020. Published: September 202020

\begin{abstract}
ABSTRAK
Abstrak - Tujuan dari penelitian untuk meningkatkan kemampuan berpikir kritis siswa dengan menggunakan model pembelajaran inkuiri terbimbing pada materi suhu dan kalor. Penelitian tindakan kelas merupakan penelitian yang dilaksanakan di kelas VII ${ }^{6}$ SMP Negeri 1 Telaga yang di ajarkan kepada 34 siswa. Lembar pengamatan aktivitas guru, lembar pengamatan aktivitas siswa dan tes kemampuan berpikir kritis siswa merupakan instrumen penelitian yang digunakan untuk pengumpulan data. Kemampuan berpikir kritis siswa dalam penelitian ini diperoleh pada siklus 1 mencapai 59\% termasuk kategori tidak kritis. Penelitian tindakan kelas pada siklus 1 hal ini menunjukan bahwa belum mencapai ketuntasan indikator pada kemampuan berpikir kritis siswa, kemampuan berpikir kritis siswa dengan dilakukan tindakan pada siklus II mencapai $80 \%$ dengan kategori sangat kritis. Hasil analisis data untuk aktivitas guru dan aktivitas siswa pada siklus II telah meningkat. Jadi dapat disimpulkan bahwa dengan menggunakan model pembelajaran inkuiri terbimbing dari hasil penelitian dapat meningkatkan kemampuan berpikir kritis siswa.
\end{abstract}

\section{Kata Kunci: Berpikir Kritis Siswa, Inkuiri Terbimbing, Suhu dan Kalor}

\section{PENDAHULUAN}

Dalam pendidikan sangat berperan penting untuk mewujudkan suatu usaha pemerintah untuk mencerdaskan kehidupan bangsa dan masa depan yang lebih dari generasi sebelumnya. Dalam proses pembelajaran siswa dapat mengembangkan kreativitas, membangun kemauan siswa, dan pendidikan diselenggarakan dengan memberi keteladanan. Pada satuan pendidikan proses pembelajaran diselenggarakan dengan interakitf, inspirasi, menggembirakan, dan dapat mendorong siswa ikut serta berperan untuk memberikan ruang yang cukup bagi gagasan, ide, daya cipta, dan

\footnotetext{
* alamat korespondensi

E-mail: abdul.haris.odja@gmail.com
} 
kemandirian sesuai dengan minat bakat dan perkembangan fisik dan psikologis siswa. Pernyataan ini lebih jelas tertulis dalam Peraturan Pemerintah Republik Indonesia Nomor 32 Tahun 2013.

Pada pembelajaran Ilmu Pengetahuan Alam (IPA) dapat mengutamakan pemberian pengalaman langsung dan memajukan suatu kompetensi agar siswa mampu menjelajahi, memahami atau menginterpretasikan untuk mengetahui sesuatu dan melakukan hal yang dapat mampu mendukung siswa agar dapat mencapai apresiasi yang lebih intensif mengenai alam sekitar (Trianto, 2010).

Salah satu kompetensi yang di harapkan untuk mencapai suatu proses pembelajaran adalah kemampuan dalam memecahkan masalah dalam ranah IPA, respon logis merupakan salah satu tujuan untuk memperbaiki dan mengembangkan kemampuan berpikir kritis siswa (Facion, 1990).

\section{KAJIAN PUSTAKA}

Berpikir kritis yaitu dimana seseorang memikirkan sebuah aktifitas yang aktif bermacam-macam hal secara lebih mendalam, menemukan informasi yang relevan, mengajukan berbagai pertanyaan, dibandingkan dari informasi yang diterima dari orang lain tersebut secara pasif (Fisher, 2009).

Para ahli sepakat dari banyaknya opini, bahwa berpikir kritis adalah untuk memecahkan suatu permasalahan dan kompetensi mampu memberikan informasi, menelaah, menyelidiki dalam penaksiran atau penilaian suatu informasi (Dixon dalam Alghafri \& Nizam, 2014).

Terdapat 12 indikator kemampuan berpikir kritis yang dirangkum ke dalam lima bagian yaitu kemampuan dalam berpikir, dimana dapat memberikannpengulasan secara lugas, dapat mengembangkan kemampuan dasar, memberikan kesimpulan, dapat mengembangkan ulasan lebih lanjut, maka dapat meningkatkan rencana dan cara. Ke 5 bagian kemampuan berpikir kritis dijabarkan dalam beberapa sub indikator tersebut yaitu; penjelasan secara singkat; (1) memusatkan permasalahan, (2) menelaah pendapat, (3) menanya dan memberikan jawaban pertanyaan. Menciptakan keterampilan dasar, (4) memperhitungkan keabsahan suatu sumber, (5) mengamati dan memperhitungkan hasil pengamatan. Memberikan kesimpuan, (6) membentuk diskusi dan memperhitungkan hasil diskusi, (7) melakukan induksi dan memperhitungkan induksi, (8) Menyusun dan memperhitungkan angka ketentuan. Menjelaskan pengulasan lanjut, (9) memberi penjelasan dalam memperhitungkan hasil, (10) memberikan penjelasan dalam hal ini sebagai asumsi. Pendekatan/cara yang dilakukan dengan terampil, (11) mengambil suatu tindakan atau keputusan, (12) melakukan interaksi antar sesama (Ennis, 1985). 
Dalam model pembelajaran inkuiri terbimbing peran guru adalah membimbing siswa untuk melakukan kegiatan secara langsung dan dapat menyediakan sarana prasarana yang dibutuhkan untuk prosedur pembelajaran sehingga siswa dapat menemukan atau mencari tahu sendiri tentang fakta, konsep, prinsip serta langkah-langkah yang dapat dipelajari untuk belajar sambil bekerja sehingga dapat mengerjakan kegiatan yang bervariasi guna mengharuskan siswa untuk mengembangkan kemampuan dan pengetahuan (Hanafiah \& Suhana, 2009)

Inkuiri terbimbing merupakan model yang menjadikan siswa dapat belajar secara mandiri dan lebih berpusat dalam mempelejarai materi dari berbagai media dan dengan mencari informasi untuk dapat membuktikan hipotesis yang sudah ditetapkan. Guru dapat memberikan sebuah persoalan dan tata cara, sedangkan siswa dapat melakukan percobaan dan merumuskan hasil dari percobaan. Inkuiri terbimbing merupakan suatu kegiatan pembelajaran yang maksimal dan dapat melibatkan kemampuan siswa untuk mencari dan dapat menyelidiki secara sistematis, kritis, dan logis. (Astuti, 2013)

Tes kemampuan berpikir kritis siswa pada materi suhu dan kalor masih berada pada kategori tidak kritis, hal ini mengakibatkan apek berpikir kritis siswa belum tercapai dengan optimal. Hal ini berdasrkan hasil yang dilakukan dari observasi diisekolah SMP Negeri 1 Telaga di kelas VII ${ }^{6}$ yang merujuk maka kemampuan berpikir kritis siswa masih di bawah rata-rata.

Yang dapat mendorong keaktifan siswa, kemandirian dan tanggung jawab dalam diri siswa dapat mengembangkan keterampilan, dapat meningkatkan pengetahuan, meningkatkan pemahaman fakta dan konsep sehingga dapat membentuk sikap yang positif terhadap ilmu pengetahuan yaitu model pembelajaran inkuiri terbimbing (Barthlow, 2011)

Agar dapat meningkatkan kemampuan berpikir kritis siswa dan mampu mengimplementasikan atas kemampuan berpikir kedalam pelajaran suhu dan kalor di kelas VII ${ }^{6}$.diharapkan dengan melalui model pembelajaran inkuiri terbimbing.

\section{METODOLOGI PENELITIAN}

Peneliti melakukan observasi awal dan memperoleh data bahwa kemampuan berpikir kritis siswa masih berada pada kategori tidak kritis. Observasition ini merupakan penelitian tindakan kelas.di laksanakan pada lokasi yang.memungkinkan untuk pelaksanaan yang dapat mencapai tujuan. Penelitian di laksanakan di SMP Negeri 1 Telaga. 
Dalam penelitian ini menggunakan analisis data meliputi: pengamatan aktivitas guru, pengamatan aktivitas siswa, dan hasil data kemampuan berpikir kritis siswa.

Analisis Kemampuan Berpikir Kritis Siswa

Setiap melalui tes kemampuan berpikir kritis siswa perolehan nilai tertulis secara dengan rumus dapat diolah:

Nilai perorangan $=\frac{\text { skor perolehan }}{\text { skor } \text { maksimal }} \times 100 \%$

Persentase tiap kategori

$=\frac{\text { Jumlah skor yang diperoleh tiap kategori tiap peserta didik }}{\text { Jumlah peserta didik keseluruhan }} \times 100 \%$

Nilai rata - rata

$=\frac{\text { Jumlah persentase tertentu seluruh soal }}{\text { jumlah total soal }} \times 100 \%$

Tabel 1 Kriteria Kempuan Berpikir Krtis Purwanto, (2004)

\begin{tabular}{ll}
\hline Rentang Nilai & Interpretasi \\
\hline $80 \%-100 \%$ & Sangat Baik \\
$70 \%-79 \%$ & Baik \\
$60 \%-69 \%$ & Cukup Baik \\
$59 \%-0 \%$ & Kurang \\
\hline
\end{tabular}

\section{HASIL DAN PEMBAHASAN}

\section{Hasil}

Dalam penelitian ini diperoleh data dari hasil yang diberikan. Dimana peneliti menggunakan test kemampuan berpikir kritis siswa berbentuk essay yang berjumlah 5 butir soal dengan 5 indikator kemampuan berpikir kritis siswa yang diberikan sebelum penerapan model pembelajaran inkuiri terbimbing.

Dalam penelitian ini adapun data yang di deskripsikan adalah pengambilan data oleh peneliti dan pengamat selama kegiatan pembelajaran berlangsung. Aspek yang diamati adalah kererlaksanaan pembelajaran guru menggunakan model pembelajaran inkuiri terbimbing dan keterlaksanaan aktivitas siswa, kemampuan berpikir kritis siswa pada mata pelajaran IPA materi suhu dan kalor. Penelitian ini merupakan jenis penelitian tindakan kelas yang dilaksanakan di kelas VII $^{6}$ SMP Negeri 1 Telaga yang diajarkan kepada 34 orang siswa dengan bertujuan untuk meneliti tentang meningkatkan kemampuan berpikir kritis siswa dengan menggunakan model pembelajaran inkuiri terbimbing pada materi suhu dan kalor di kelas VII ${ }^{6}$ SMP Negeri 1 Telaga. 


\section{Deskripsr Keterlaksanaan Pembelajaran}

Kegiatan ini dilaksanakan sebanyak empat kali pertemuan yang terdiri dari siklus 1 dan siklus II yang dipantau dan dinilai oleh satu orang pengamat yakni guru mata pelajaran IPA yang ada di sekolah guna mengamati kekurangan-kekurangan dalam proses pembelajaran. Aktivitas guru ini menggambarkan seberapa jauh guru telah menerapkan model pembelajaran inukiri terbimbing. Pengamatan aktivitas guru pada model pembelajaran inkuiri terbimbing yang dinilai melalui lembar observasi berdasarkan langkah-langkah pembelajaran yang dilakukan oleh guru. Lembar observasi keterlaksanaan RPP dilakukan oleh satu orang pengamat yaitu guru mata pelajaran dilihat setiap kali pertemuan dan memiliki kriteria penilaian yaitu 4 sangat baik, 3 baik, 2 cukup dan 1 kurang. Perentase keterlaksanaan pembelajaran sebagai berikut.

\section{Deskripsi Aktivitas Guru}

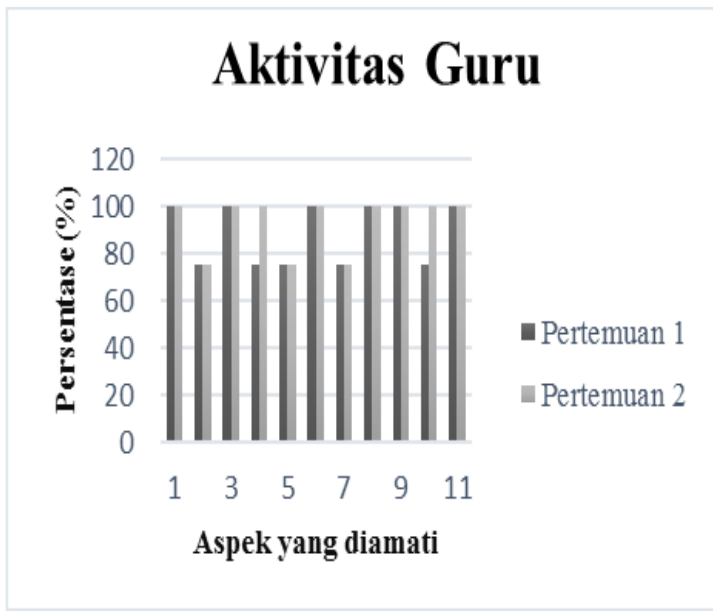

Gambar 1. Hasil Aktivitas Guru Siklus 1

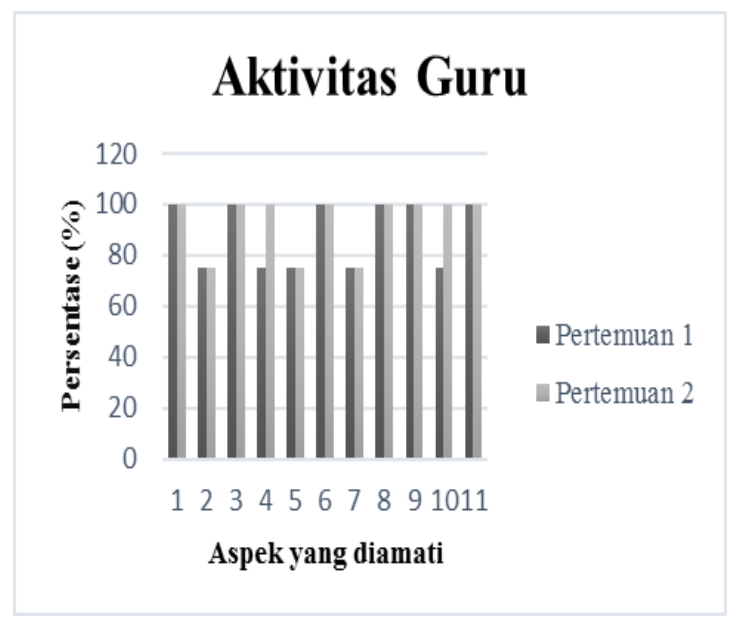

Gambar 2. Hasil Aktivitas Guru Siklus II

\section{Deskripsi Aktivitas siswa}

Berdasarkan observasi oleh dua pengamat, peningkatan aktivitas siswa pada setiap pertemuan pengamatan aktivitas siswa dilakukan dengan dua siklus, yaitu siklus 1 dan siklus II. Lembar observasi aktivitas siswa menggunakan 9 aspek yang diamati pada pembelajaran berlangsung. Peningkatan aktivitas siswa dapat diketahui melalui pengolahan dan analisis data. menggunakan lembar observasi aktivitas siswa yang dinilai pada setiap pertemuan oleh dua pengamat. 


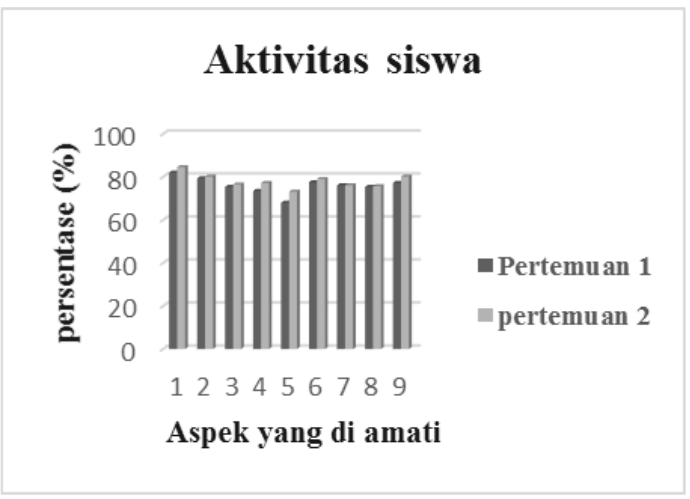

Gambar 3. Hasil Aktivitas Siswa Siklus 1

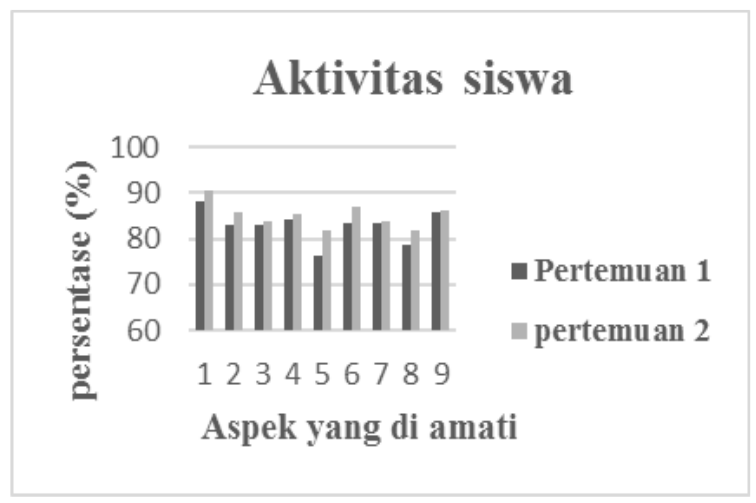

Gambar 4. Hasil Aktivitas Siswa Siklus II

\section{Hasil Kemampuan Berpikir Kritis Siswa}

Untuk mengetahui peningkatan kemampuan berpikir kritis siswa maka perlu dilakukan pengolahan dan analisis data. Tes ini dilakukan sebanyak dua kali yaitu pada siklus 1 dan siklus II. Pengamatan kemampuan berpikir kritis siswa dinilai dengan menggunakan tes kemampuan berpikir kritis siswa berbentuk essay yang dinilai berdasarkan indikator kemampuan berpikir kritis menurut Ennis.

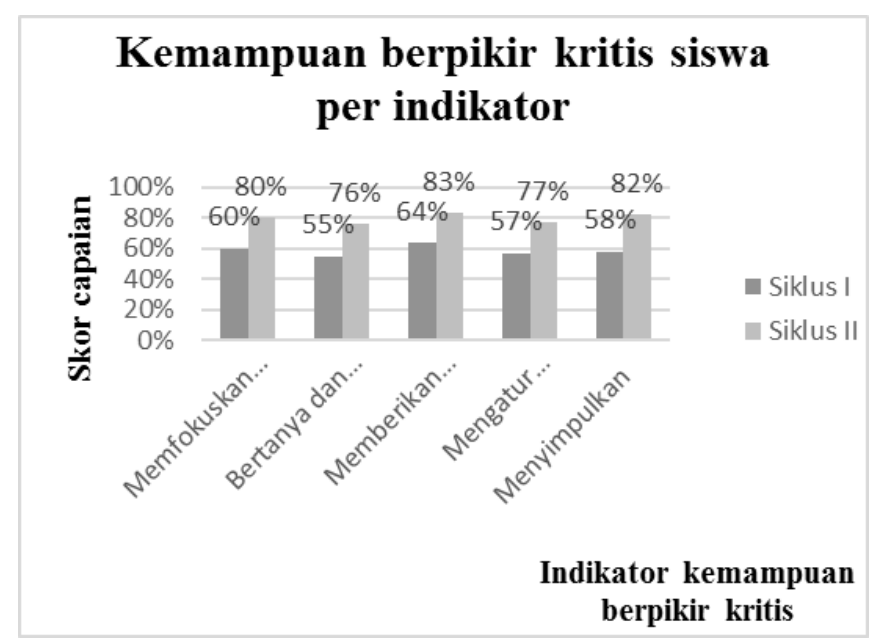

Gambar 5. Hasil Kemampuan Bepikir Kritis Siklus 1 dan Siklus II

Kemampuan berpikir kritis siswa dalam menjawab soal pada siklus 1 dan siklus II ditunjukan oleh skor rata-rata. pada siklus 1 menunjukkan 59\% meningkat menjadi $80 \%$ pada siklus II, sehingga terdapat $21 \%$ untuk peningkatan kemampuan berpikir kritis siswa. Hal ini dapat diktahui bahwa setelah menggunakan model pembelajaran inkuiri terbimbing berdasarkan pada gambar 6. 


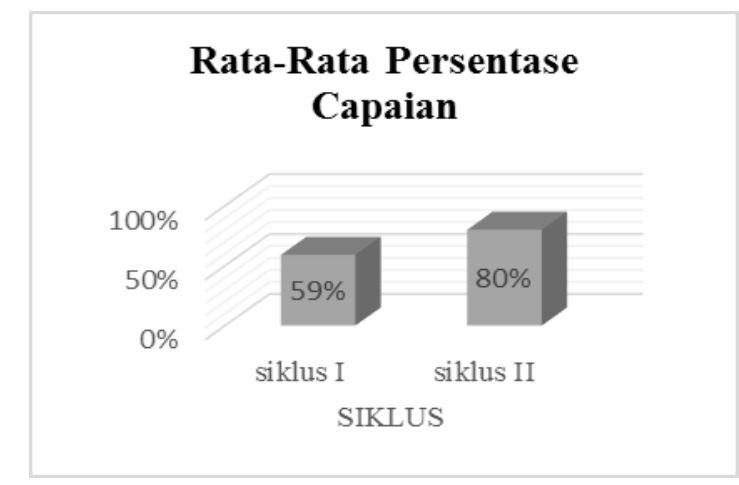

Tabel 6 Rata-rata kemampuan berpikir kritis

\section{Pembahasan}

Sebelum melakukan penelitian terlebih dahulu yang dilakukan oleh peneliti yaitu melakukan validasi yang bertujuan untuk kelayakan perangkat pembelajaran yang akan digunakan sebagai tolak ukur untuk penelitian. Perangkat yang digunakan untuk menunjang suatu keberhasilan penelitian yaitu berupa lembar pengamatan kegiatan aktivitas guru, lembar pengamatan aktivitas siswa, dan tes kemampuan berpikir kritis. Penelitian yang dilakukan adalah penelitian tindakan kelas (PTK). Berdasarkan data hasil penelitian ini dilaksanakan di kelas VII ${ }^{6}$ SMP Negeri 1 Telaga. Penelitian tindakan kelas ini bertujuan untuk meningkatkan kemampuan berpikir kritis siswa dengan menggunakan model pembelajaran inkuiri terbimbing pada materi suhu dan kalor.

Setelah proses pembelajaran pada materi suhu dan kalor selesai, siswa kembali diberikan tes kemampuan berpikir kritis. Selain itu pada penelitian ini juga menggunakan lembar observasi aktivitas siswa untuk melihat keaktivan siswa dalam proses pembelajaran dengan menggunakan model pembelajaran inkuiri terbimbing yang di amati pada setiap pertemuan oleh 2 pengamat, dan menggunakan lembar keterlaksanaan RPP untuk menilai aktivitas guru dalam menerapkan model pembelajaran inkuiri terbimbing sesuai dengan langkah-langkah pada RPP, yang diamati pada setiap pertemuan oleh guru mata pelajaran.

Hal ini sesuai dengan yang diungkapkan Ennis (1985) berpikir kritis adalah sebuah aktifitas aktif baik pembelajaran atau diluar pembelajaran dimana seseorang memikirkan bermacam-macam hal secara lebih mendalam, mengajukan berbagai pertanyaan, menemukan informasi yang relevan. Seluruh indikator kemampuan berpikir dapat ditingkatkan melalui pembelajaran. Saat pembelajaran inkuiri tercipta berbagai kegiatan yang terkait secara langsung dan tidak langsung dengan indikator berpikir kritis. Dari analisis siklus 1 dan siklus 2 terjadi peningkatan berbagai aspek yang terkait dengan berpikir kritis melalui pembelajaran inkuiri terbimbing. Hasil penelitian sesuai dengan hasil penelitian Arota Morsalin dan Odja (2020) melalui pembelajaran PBL melalui $e$ - 
learning dapat meningkatkan kemampuan berpikir kritis siswa. Demikian juga penelitian Sochibin dan Marwoto (2009) menemukan hal yang sama yakni pembelajaran inkuiri terbimbing di SD meningkatkan kemampuan berpikir kritis pada air dan sifatnya.

\section{KESIMPULAN}

Tes hasil kemampuan berpikir kritis siswa dengan menggunakan model pembelajaran inkuiri terbimbing ini menunjukkan peningkatan yang terjadi dari siklus I ke siklus II. Hal ini terlihat pada siklus I menunjukan bahwa kemampuan berpikir kritis siswa kelas VII ${ }^{6}$ yang berjumlah 34 orang ada 17 siswa mencapai $50 \%$ termasuk pada kategori tidak kritis, 8 orang siswa mencapai $24 \%$ kategori kurang kritis, 5 siswa mencapai kategori kritis dengan persentase $15 \%$ dan 4 orang siswa mencapai kategori sangat kritis dengan persentase $12 \%$. Untuk memperbaiki proses pembelajaran dalam kelas yaitu dengan menggunakan model pembelajaran inkuiri terbimbing untuk meningkatkan kemampuan berpikir kritis siswa. Kategori kemampuan berpikir kritis yang meningkat pada siklus II yaitu sangat kritis 18 orang mencapai 53\%, kategori kritis 10 orang mencapai $29 \%$ dan kategori kurang kritis 6 orang dengan mencapai 18\%. Adapun pada masing-masing indikator kemampuan berpikir kritis yaitu memfokuskan pertanyaan $80 \%$, bertanya dan menjawab pertanyaan $76 \%$, memberikan penjelasan $83 \%$, mengatur strategi dan taktik $77 \%$ dan menyimpulkan $82 \%$. Berdasarkan hasil penelitian dan pembahasan sehingga dapat disimpulkan bahwa kegiatan pembelajaran dengan menggunakan model pembelajaran inkuiri terbimbing terlaksana dengan baik serta dapat meninkatkan kemampuan berpikir kritis siswa dan model pembelajaran tersebut cocok digunakan pada materi suhu dan kalor di kelas VII ${ }^{6}$ SMP Negeri 1 Telaga

Saran

a. Diharapkan guru dapat mengembangkan kemampuan berpikir kritis siswa dan dapat meningkatkan kualitas pendidikan yang terfokus dan guru dapat memilih menggunakan model yang lebih relevan untuk melaksanakan pembelajaran dan pengetahuan tentang berbagai model pembelajaran.

b. Diharapakan guru dapat mengembangkan dan meningkatkan kualitas pendidikan terutama memiliki pengetahuan atas berbagai strategi pembelajaran yang dapat meningkatkan kemampuan berpikir kritis siswa. 


\section{REFERENSI}

Alghafri, S., Ali, \& Nizam, H. (2014). The effectts of integrating creative and critical thinking on schools students thinking. International Journal of Social Science and Humanity.Vol. 4, No. 6.

Astuti, Y. \& B. Setiawan. 2013. Pengembangan Lembar Kerja Siswa (LKS) Berbasis Pendekatan Inkuiri Terbimbing dalam Pembelajaran Kooperatif pada Materi Kalor. Jurnal Pendidikan IPA Indonesia.

Arota, Anjas. Mursalin. Odja, Abdul Haris. (2020). The effectiveness of e-learning based on SETS to improve students' critical thinking skills in optical instrument material. Journal of Physics: Conference Series, 1521 (2020) 022061

Barthlow, M. J. (2011). The Effecttiveness of Process Oriented Guided Inquiry Learning to Reduce Alternate Concepion in Secondary Chemistry. Lynchburg: Liberty University.

Ennis, R. H. 1985. Goals for A Critical Thinkling Curriculum. Costa, A.L., (Ed). Developing Minds A Resource Book for Teaching Thinking. Alexandra, Virginia: Assosiation for Supervision and Currulum Development (ASCD).

Sochibin, A. Dwijananti, P. Marwoto. (2009) Penerapan Model Pembelajaran Inkuiri Terpimpin Untuk Peningkatan Pemahaman Dan Keterampilan Berpikir Kritis Siswa SD. Vol 5 (2).

Fisher, Alec. 2009. Berpikir Kritis Sebuah Pengantar. Jakarta: Erlangga

Facion, Peter A. 1990. Critical Thinking: A Statment of Epert Consesus For Purpupos Of Education Asessment And Instruction. California Stat University

Hanafiah, N. \& Suhana, C. 2009. Konsep Strategi Pembelajaran. Bandung: PT Refika Aditama

Purwanto, M. N. (2004). Prinsip-Prinsip dan Teknik Evaluasi Pengajaran. Bandung: PT Remaja Rosdakarya.

Trianto, 2010. Model Pembelajaran Terpadu, Konsep, Strategi dan Implementasinya dalam Kurikulum Tingkat Satuan Pendidikan (KTSP). Bumi Aksara.Jakarta. 